\title{
The influence of clinical and chronic forms of magnesium deficiency on the haematological parameters of dairy cows
}

\author{
Beata Abramowicz, Krzysztof Lutnicki, and Lukasz Kurek* \\ Department and Clinic of Animal Internal Diseases, Faculty of Veterinary Medicine. University of Life Sciences, \\ Lublin, Poland
}

\begin{abstract}
ABRAMOWICZ, B., K. LUTNICKI, $L$. KUREK: The influence of clinical and chronic forms of magnesium deficiency on the haematological parameters of dairy cows. Vet. arhiv 91, 117-124, 2021.
\end{abstract}

\section{ABSTRACT}

The aim of the study was to determine the influence of hypomagnesaemia on the haematological status and predictive values of haematological tests in the diagnosis of magnesium $(\mathrm{Mg})$ deficiency in dairy cow herds. The study was carried out on 100 dairy HF cows, divided into two experimental groups and a control one.The two experimental groups (I - clinical form of hypomagnesaemia, II - chronic form of hypomagnesaemia) consisted of 40 cows and the control group consisted of 20 healthy cows. Blood samples were collected twice: before the commencement of the therapy and after three months. In both hypomagnesaemic groups, low erythrocyte count, haemoglobin (Hgb) concentration and hematocrit $(\mathrm{Ht})$ index values were observed. The indirect parameters of the erythrocyte system were within the standard reference range, with the exception of the mean corpuscular hemoglobin $(\mathrm{MCH})$ index, which, in approx. $45 \%$ of animals, was below the lower limit of the normal range. Haemolytic normocytic normochromic anaemia was detected through the hypomagnesaemia of the cows. In the first and second group, at the first blood sampling an increase in the eosinophil count was observed, which was statistically significant in relation to the second sampling. In the blood smear test, a variety of erythrocyte sizes (anisocytosis), polychromasia and Howell-Jolly bodies were detected in the affected cows. After supplementation with magnesium, the concentration of $\mathrm{Mg}$ in the serum of the treated animals returned to normal more rapidly than the haematological parameters. The authors assumed that these in the haematological parameters may be helpful in indicating the need for $\mathrm{Mg}$ supplementation.

Key words: haematology; hypomagnesaemia; cattle; haemolytic anaemia

\section{Introduction}

Metabolic diseases in high-yield dairy cattle herds are still their main health problem, despite the increasingly accurate balancing of feed doses and the application of directed prevention. One of the commonly occurring mineral homeostasis disorders is magnesium deficiency $(\mathrm{Mg})$. Currently, the chronic form of this deficiency is more frequent and often causes greater financial losses than the clinical or subclinical forms. The acute and subacute forms are quite straightforward to diagnose clinically, while the chronic form is extremely difficult to diagnose due to variations in $\mathrm{Mg}$ levels in the blood over a 24-hour period (SCHONEWILLE et al., 1999; MARTENS and SCHWEIGEL, 2000;

\footnotetext{
*Corresponding author:

PhD, DVM Łukasz Kurek, Department and Clinic of Animal Internal Diseases, Faculty of Veterinary Medicine, University of Life Science Lublin, Głęboka 30,20-950 Lublin, Poland, E-mail: lukasz.kurek@up.lublin.pl
} 
SWAMINATHAN, 2003; GOFF, 2004; GOFF, 2006; GOFF, 2008). Hypomagnesaemia in an acute or subacute form is most often manifested by the following symptoms: appetite disturbances, hyperactivity, psychomotor agitation and a decrease in milk production. In cows, we may observe the following manifestations: stiff and straight auricles, the gnashing of teeth, muscle tremors, stiff gait, nystagmus or exophthalmos (SCHONEWILLE et al., 1999; MARTENS and SCHWEIGEL, 2000; GOFF, 2004; GOFF, 2006). Chronic Mg deficiency is characterized by nonspecific symptoms, such as a changeable appetite, decreased milk yield, lameness, reproductive problems, and an increased susceptibility to infection (MARTENS and SCHWEIGEL, 2000; GOFF, 2006; GOFF, 2008). Hyperactivity may occasionally occur during normal zoohygienic procedures and animal handling. The available literature lacks precise guidelines for the diagnosis and treatment of this form of hypomagnesaemia in dairy cattle herds. There is an ongoing search for rapid and inexpensive methods that would, during routine screening tests, indicate the possibility of the occurrence of mineral deficiencies in the herd and justify the implementation of comprehensive biochemical testing in order to confirm or exclude this problem.

The literature data provide little information concerning the effect of magnesium deficiency on the haematological parameters of livestock, and only a handful of experimental studies have reported anaemia in rats (PIOMELLI et al., 1973). In humans, over the course of magnesium deficiency, the occurrence of haemolytic anaemia has been observed (SHI et al., 2008; ZHAN et al., 2014; YIN et al., 2015). CINAR et al. (2007) observed that $\mathrm{Mg}$ supplementation increases the number of erythrocytes and the concentration of $\mathrm{Hgb}$ in the blood of athletes. The literature concerning cattle lacks data about the relationship between the haematopoietic system and $\mathrm{Mg}$ homeostasis.

The aim of this study was to evaluate the effect of hypomagnesaemia on the haematological status of dairy cows and the possible applicability of routine haematological tests to predict the occurrence and treatment of hypomagnesaemia in a herd.

\section{Materials and methods}

The study was carried out on 100 dairy HF cows, which were 3 to 5 years old, with 500 - $600 \mathrm{~kg}$ body weight, and BCS $3.25-3.75$. The milk yield during the last lactation period was about $9000 \mathrm{~L}$, the cattle were all at between 3 to 5 weeks post-parturition, and their nutrition was based on the TMR method. The nutritional doses were adjusted to the current dairy production, the physiological period, as well as to the age and weight of the animals. The feed ration contained maize silage, maize grain, grass based haylage, hay, straw, cereal mix (barley, wheat, oats), a protein supplement (18\%), and mineral and vitamin supplements (with an Mg content of 4\%).

On the basis of the clinical examination and biochemical blood tests, the cows were divided into 3 groups. Group I consisted of 40 cows with acute and subacute forms of $\mathrm{Mg}$ deficiency (the average $\mathrm{Mg}$ concentration in the blood serum was 0.45 $\mathrm{mmol} / \mathrm{l})$. In these animals, increased sensitivity to environmental stimuli, periodic tonic-clonic contractions of the large muscles, exophthalmia, nystagmus and stiffness of the ear pinnae, and paleness of the mucous membranes were observed.

Group II (with the chronic form of deficiency) consisted of 40 cows with an average $\mathrm{Mg}$ concentration in the serum of $0.67 \mathrm{mmol} / \mathrm{l}$. The owners of these cows reported that there were periodic problems with appetite, rumination disorders and that some of the animals were restless, and a decrease in milk yield had been observed. In addition, lameness and an increased susceptibility to infections were noted.

Group III (control) consisted of 20 animals that were healthy in clinical and laboratory tests.

The cows in all groups originated from herds under comprehensive veterinary control. Cows were not included in the study if there were any disturbances in the concentrations of phosphorus, calcium and copper in their blood. They were also excluded from the study if clinical and laboratory examinations indicated a parenchymatous organ disorder, or if they had a history of difficult calving, or had suffered muscle damage, lameness or metabolic diseases upon calving. 
B. Abramowicz et al.: The influence of magnesium deficiency on the haematological parameters of dairy cows.

The blood was collected twice: before the commencement of the treatment and three months after the application of the Mg supplement. Each blood sampling was preceded by a detailed medical interview and clinical examination, and the feeding regime and the composition of the feed, as well as the milk yield were evaluated. Blood was collected from the external jugular vein and transferred into $\mathrm{K}_{2}$ EDTA tubes (for the morphological examination ofblood) and into test tubes containing a clot activator in order to obtain serum for biochemical analysis.

In group I, the animals were treated with a preparation containing magnesium at a concentration of $200 \mathrm{mg} / \mathrm{mL}$, dosed at $0.25 \mathrm{~mL} / \mathrm{kg}$ of body weight i.v. twice a day. After clinical symptoms resolved, the treatment was continued using a mineral feed additive with an increased magnesium content of up to $7 \%$, which contained magnesium sulphate and magnesium oxide. In group II, after the deficiency was diagnosed, the routinely used mineral-vitamin additive was changed to a preparation with an increased $\mathrm{Mg}$ content $(7 \%)$. In both of the groups studied, the administration of the preparation continued for three months until normal levels of $\mathrm{Mg}$ in the blood were detected.

\section{Results}

The results are presented in Table 1. For the groups of animals studied, after a three-month period of supplementation with an increased dose of magnesium and the normalization of its concentration, we observed a decrease in susceptibility to infections and a reduction in the occurrence of lameness by over $70 \%$.

The lowest values of the erythrocyte count that were statistically significant $(\mathrm{P}<0.05)$ were detected at the first blood sampling in a group of animals with a clinical form of $\mathrm{Mg}$ deficiency (group I) and it was statistically significantly lower $(\mathrm{P}<0.001)$ than the values determined at the second sampling. A low haemoglobin concentration was found for both sampling events in groups I and II, however, the $\mathrm{Hgb}$ concentration was statistically significantly higher after $\mathrm{Mg}$ supplementation. The Ht value for group I was significantly lower $(\mathrm{P}<0.01)$ at the first
In the morphological examination, the direct parameters of the erythrocyte system (erythrocyte count - RBC, haemoglobin concentration - Hgb, haematocrit index - Ht), indirect parameters of the erythrocyte system (mean corpuscular volume - MCV, mean corpuscular haemoglobin - MCH, mean corpuscular haemoglobin concentration $\mathrm{MCHC}$ ) and the leukocyte count (WBCs as well as the platelet count, - PLT), were determined using a Horiba scil Vet abc Plus automatic analyser. Also, from manual blood smears stained using the May-Grünwald-Giemza method, the percentages of neutrophils $(\mathrm{N})$, eosinophils (E) and basophils (B), lymphocytes (L) and monocytes (M) were calculated. The total $\mathrm{Mg}$ concentration in the serum was determined by photometric test using xylidyl blue, with the use of a Mindray BS-130 automatic analyser.

The results were subjected to mathematical statistical analysis and the significance of the differences between the individual groups was calculated using the Mann-Whitney U rank test. The calculations were made at a significance level of $\mathrm{P}<0.05$.

sampling compared with the second sample, and the Ht value was statistically significantly lower at the first sampling in group I than for the first sample in group II $(\mathrm{P}<0.05)$, and the control group $(\mathrm{P}<0.01)$. The haematocrit index at the first sampling in group II was statistically significantly lower $(\mathrm{P}<0.05)$ than it was at the second sampling. The mean values of the indirect parameters of the red blood cell system were within the normal reference range. In group II at the first sampling, values below the normal reference range were found for the $\mathrm{MCH}$ index (in approx. $45 \%$ of animals - 18 cows) and for the MCV index (in approx. 10\% of cases - 4 cows).

In the white blood cell system, the number of leukocytes was within the standard reference range. The decrease in the percentage of segmented neutrophils which was observed in group I at the first sampling was not statistically significant. A 
B. Abramowicz et al.: The influence of magnesium deficiency on the haematological parameters of dairy cows

Table 1. Mean haematological parameters and magnesium concentrations in the blood of the examined cows

\begin{tabular}{|c|c|c|c|c|c|c|c|}
\hline \multirow[b]{2}{*}{ Parameters } & \multirow[b]{2}{*}{$\begin{array}{l}\text { Bovine } \\
\text { reference } \\
\text { intervals* }\end{array}$} & \multicolumn{2}{|c|}{$\begin{array}{c}\text { Group I } \\
\mathrm{n}=40\end{array}$} & \multicolumn{2}{|c|}{$\begin{array}{c}\text { Group II } \\
\mathrm{n}=40\end{array}$} & \multicolumn{2}{|c|}{$\begin{array}{c}\text { Control group } \\
n=20\end{array}$} \\
\hline & & $\begin{array}{c}1^{\text {st }} \\
\text { blood } \\
\text { sampling }\end{array}$ & $\begin{array}{c}2^{\text {nd }} \\
\text { blood } \\
\text { sampling }\end{array}$ & \begin{tabular}{c|}
$1^{\text {st }}$ \\
blood \\
sampling \\
\end{tabular} & $\begin{array}{c}2^{\text {nd }} \\
\text { blood } \\
\text { sampling }\end{array}$ & $\begin{array}{c}1^{\text {st }} \\
\text { blood } \\
\text { sampling }\end{array}$ & $\begin{array}{c}2^{\text {nd }} \\
\text { blood } \\
\text { sampling }\end{array}$ \\
\hline $\begin{array}{l}\mathrm{RBC} \\
\times 10^{12} / \mathrm{L}\end{array}$ & $5-7$ & $4.65 \pm 0.70$ & $6.63 \pm 0.99$ & $6.60 \pm 1.70$ & $7.10 \pm 0.27$ & $7.39 \pm 1.38$ & $7.25 \pm 0.45$ \\
\hline $\mathrm{Hb}(\mathrm{g} / \mathrm{L})$ & $105-140$ & $73.50 \pm 11.6$ & $97.40 \pm 13.3$ & $94.30 \pm 19.1$ & $100.1 \pm 10.2$ & $111.67 \pm 12.71$ & $107 \pm 10.68$ \\
\hline Hct (L/L) & $0.30-0.40$ & $0.23 \pm 0.04$ & $0.30 \pm 0.04$ & $0.29 \pm 0.06$ & $0.31 \pm 0.03$ & $0.33 \pm 0.04$ & $0.33 \pm 0.03$ \\
\hline $\begin{array}{l}\text { MCV } \\
(\mathrm{fL})\end{array}$ & $40-60$ & $49.25 \pm 2.71$ & $45.32 \pm 4.84$ & $45.86 \pm 5.33$ & $45.29 \pm 3.02$ & $43.76 \pm 5.54$ & $45.23 \pm 2.14$ \\
\hline $\begin{array}{l}\mathrm{MCH} \\
(\mathrm{fmol})\end{array}$ & $0.9-1.5$ & $0.98 \pm 0.06$ & $0.95 \pm 0.08$ & $0.90 \pm 0.11$ & $0.93 \pm 0.07$ & $1.12 \pm 0.14$ & $0.91 \pm 0.05$ \\
\hline $\begin{array}{l}\mathrm{MCHC} \\
(\mathrm{mmol} / \mathrm{L})\end{array}$ & $16-21$ & $19.86 \pm 0.44$ & $19.80 \pm 0.39$ & $19.58 \pm 0.39$ & $20.48 \pm 0.30$ & $21.63 \pm 0.87$ & $20.27 \pm 1.26$ \\
\hline $\begin{array}{l}\mathrm{WBC} \\
\times 10^{9} / \mathrm{L}\end{array}$ & $6.2-9.5$ & $6.78 \pm 3.48$ & $6.23 \pm 1.88$ & $6.65 \pm 2.00$ & $6.31 \pm 1.24$ & $10.86 \pm 0.55$ & $7.73 \pm 0.72$ \\
\hline $\mathrm{BN}(\%)$ & $0-2$ & $1.00 \pm 0.00$ & $1.00 \pm 0.00$ & $1.00 \pm 0.00$ & $1.00 \pm 0.00$ & $1.6 \pm 0.55$ & $1.00 \pm 0.00$ \\
\hline $\mathrm{SN}(\%)$ & $23-37$ & $20.25 \pm 10.40$ & $28.89 \pm 16.82$ & $25.07 \pm 6.59$ & $23.57 \pm 3.67$ & $33.50 \pm 2.88$ & $40.43 \pm 6.24$ \\
\hline $\mathrm{E}(\%)$ & $1-7$ & $16.38 \pm 11.41$ & $8.42 \pm 5.08$ & $18.86 \pm 13.20$ & $5.57 \pm 1.22$ & $3.00 \pm 1.23$ & $4.14 \pm 1.77$ \\
\hline $\mathrm{B}(\%)$ & $0-1$ & $1.50 \pm 0.84$ & $2.00 \pm 1.32$ & $1.18 \pm 0.40$ & $2.33 \pm 1.11$ & $1.20 \pm 0.45$ & $1.00 \pm 0.00$ \\
\hline $\mathrm{L}(\%)$ & $53-67$ & $58.00 \pm 20.08$ & $57.63 \pm 18.13$ & $47.38 \pm 8.96$ & $66.86 \pm 5.31$ & $59.83 \pm 2.14$ & $52.00 \pm 6.45$ \\
\hline $\mathrm{M}(\%)$ & $0-4$ & $4.00 \pm 2.98$ & $3.75 \pm 3.09$ & $5.21 \pm 3.40$ & $3.00 \pm 1.43$ & $1.40 \pm 0.55$ & $1.86 \pm 0.69$ \\
\hline $\begin{array}{l}\mathrm{PLT} \\
\times 10^{9} / \mathrm{L} \\
\end{array}$ & $200-800$ & $\begin{array}{c}292.88 \pm \\
111.06 \\
\end{array}$ & $\begin{array}{c}379.00 \pm \\
148.84 \\
\end{array}$ & $\begin{array}{l}360.62 \\
\pm 149.21 \\
\end{array}$ & $\begin{array}{l}406.86 \\
\pm 19.88 \\
\end{array}$ & $\begin{array}{c}327 \\
\pm 38.27 \\
\end{array}$ & $\begin{array}{l}345.29 \\
\pm 50.30 \\
\end{array}$ \\
\hline $\begin{array}{l}\mathrm{Mg} \\
(\mathrm{mmol} / \mathrm{L})\end{array}$ & $0.78-1.23$ & $0.45 \pm 0.09$ & $0.91 \pm 0.07$ & $0.67 \pm 0.03$ & $0.89 \pm 0.03$ & $1.07 \pm 0.08$ & $0.88 \pm 0.09$ \\
\hline
\end{tabular}

*Baumgartner (2005), RBC - erythrocyte number, Hb - haemoglobin, Ht - haematocrit, MCV - mean corpuscular volume, $\mathrm{MCH}$ - average haemoglobin content in erythrocytes, MCHC - mean haemoglobin concentration in erythrocytes, WBC - leukocyte number, BN - Band neutrophils, SN - Segmented neutrophils, E - Eosinophils, B - Basophils, L - Lymphocytes, M - Monocytes
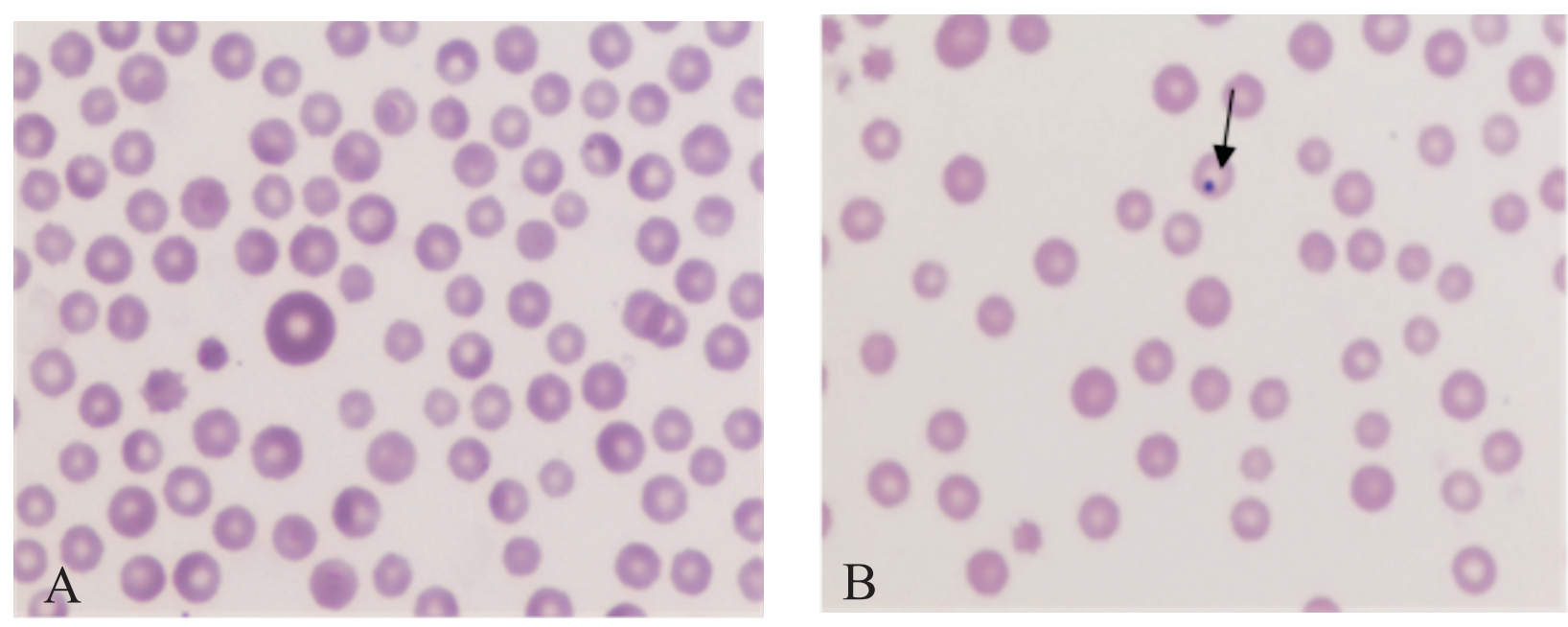

Fig. 1. Changes in the erythrocytes: A - Varying erythrocyte sizes in the blood smear sample (anisocytosis), polychromasia, B - A Howell-Jolly body (as indicated by the arrow) 
B. Abramowicz et al.: The influence of magnesium deficiency on the haematological parameters of dairy cows.

statistically significant increase in the percentage of eosinophils $(\mathrm{P}<0.05)$ was only noted between the first and second samplings in group II. A significant $(\mathrm{P}<0.001)$ drop in the percentage of lymphocytes was observed in group II at the first sampling in relation to the second sampling. An increase was observed in the percentage of basophils for two collections in group I and II, as well as an increase in the monocytes at the first sampling in group II. This increase was not statistically significant.

The parameters of the platelet values determined were within the standard reference range and did not show any statistically significant differences.

For the blood smear test, a variety of erythrocyte sizes (anisocytosis) were observed in all tested animals in groups I and II. In addition, polychromasia was observed (in 5 cows in group I and 32 in group II) and the body of Howell-Jolly (in 19 animals in group I and 33 in group II) (Fig. 1).

\section{Discussion}

Bovine hypomagnesaemia is becoming more and more common on farms due to rising milk production, mainly in its chronic form (SUTTLE, 2010). The treatment for hypomagnesaemia is usually long lasting with no satisfactory results. The preparations applied in the prophylaxis of cattle deficiency diseases are most often directed towards the treatment of calcium deficiency and contain an insufficient amount of $\mathrm{Mg}$. This in turn results in the necessity for long-term oral magnesium supplementation, lasting for many months, in order to achieve a compensation effect. Due to the presence of chronic subclinical cases, the laboratory monitoring of $\mathrm{Mg}$ concentration in serum is largely insufficient and a preferable solution would be to monitor the general health status of the herd. The metabolic profiles commonly used in routine herd management which are complemented with haematological tests are considered to be a useful strategy for the prophylaxis and treatment of hypomagnesaemia.

Over the course of hypomagnesaemia, in both its acute and subacute forms, for the most part a decrease in the direct red blood cell parameters was found. It was noted that the erythrocyte count,
$\mathrm{Hgb}$ concentration and $\mathrm{Ht}$ index decreased. The most advanced changes occurred in animals in the group with the clinical symptoms of magnesium deficiency. O)n the basis of these results, it may be concluded that $\mathrm{Mg}$ deficiency contributes to the occurrence of anaemia in dairy cattle. This finding has also been confirmed by other authors, where relevant results were obtained from investigations on humans and rats (PIOMELLI et al., 1973; SHI et al., 2008; ZHAN et al., 2014). In humans, the haemoglobin concentration was found to decrease with falling $\mathrm{Mg}$ blood concentrations, but the authors did not provide any explanation about the way in which the erythrocyte count and the value of $\mathrm{Ht}$ changed. As the result of a study conducted on the blood parameters of rats, it was found that, in cases of hypomagnesaemia, the Hgb concentration and the $\mathrm{Ht}$ index decreased, whereas the number of erythrocytes remained within the reference range. In another study by COSENS et al. (1977) which concerned experimentally induced hypomagnesaemia lasting for three weeks in rats, the occurrence of haemolytic anaemia, macrocytosis and poikilocytosis was observed. PIOMELLI et al. (1973) noted in their research the presence of normochromic microcytic anaemia. From our research, similar results were obtained for $10 \%$ of the animals in group II, in which we observed a decrease in the MCV index (microcytic anaemia) and anisocytosis of erythrocytes.

The pathomechanism of anaemia affected by hypomagnesaemia has not yet been elucidated. PIOMELLI et al. (1973) showed that haemolytic anaemia, in the course of hypomagnesaemia, may be the result of disturbances in the energy metabolism of erythrocytes. In a study concerning the metabolic effects of $\mathrm{Mg}$ deficiency, it was observed that $\mathrm{Mg}$ deficiency reduced the life span of erythrocytes in the bloodstream. Low levels of $\mathrm{Mg}$ also contributed to the dehydration of erythrocytes and the formation of sickle cells. Oral magnesium supplementation significantly reduced erythrocyte dehydration in people suffering from sickle cell anaemia (SHI et al., 2008). While studying the RBC under an electron microscope, ELIN et al. (1980) observed granules on the surface of the erythrocytes, which, with the aging of the cell, were transformed into 
deposits on the surface of the blood cell that eventually caused the cell membrane to rupture and erythrocyte breakdown. In the case of $\mathrm{Mg}$ deficiency, the red blood cells aged more rapidly, and the transformation of granular inclusions into deposits was observed. This factor shortened the life span of the erythrocytes in the bloodstream. Moreover, ELIN et al. (1980) observed an increased number of reticulocytes in hypomagnesaemic animals, which was indicative of the regeneration of the red blood cell system. In our studies, numerous Howell-Jolly bodies and the significant anisocytosis of erythrocytes and polychromasia were detected in blood smears from hypomagnesaemic cows. These changes indicate the renewal of the red blood cell system and the presence of haemolytic anaemia (BAIN, 2017).

In our research, the average values of the indirect parameters ( $\mathrm{MCV}, \mathrm{MCH}$ and $\mathrm{MCHC}$ ) of the erythrocyte system lay within the standard reference ranges, despite a significant reduction in serum $\mathrm{Mg}$ concentration. However, if this is accompanied by a decrease in the direct parameters of the erythrocyte system, it may be a predictive symptom of normocytic normochromic anaemia. Simultaneously, in almost $45 \%$ of the animals in group II, a decrease in the $\mathrm{MCH}$ index was noted, which indicates the possibility of hypochromic anaemia. This is a new observation, which has not appeared in the literature to date.

After Mg supplementation, all clinical symptoms disappeared, and an increase in red blood cell parameters was detected after the treatment of clinical as well as chronic forms of the deficiency, but some of the red blood cell parameters did not return to normal levels. There was an increase in the red blood cell count in most animals, while the $\mathrm{Hgb}$ concentration and $\mathrm{Ht}$ index were below the lower limit of the standard reference range in more than half of the animals. The equalization of the red blood cell parameters was not as effective when compared to a similar study conducted on humans (CINAR et al., 2007). Adult cattle absorb magnesium more slowly and in a smaller amount than monogastric animals, which is a result of the specificity of the gastrointestinal tract. Therefore, on the basis of the research conducted, it may be concluded that the amount of this element in the mineral supplements used in the treatment of $\mathrm{Mg}$ deficiency should be higher, or that supplementation should take place over a longer time. In the examined animals, changes in the white blood cell system as a response to hypomagnesaemia were also observed, which may be crucial to the functioning of the immune system (ORDEN et al., 2006). In both the hypomagnesaemic groups, there was an increase in the percentage of eosinophils at the first sampling, which, after the restoration of normal $\mathrm{Mg}$ concentrations, returned to values within the standard reference range. In addition, mild neutropenia was observed over the course of the clinical form of the disease. In experimental studies with rats, neutrophilia and eosinophilia occurred (ORDEN et al., 2006). These changes may be explained by the reaction of the leukocyte subpopulation to acute inflammation during magnesium deficiency. There are some papers concerning metabolic and mineral deficiencies in cows, where the inflammation status is described (GOFF, 2004; GLOMBOWSKY et al., 2018). In cattle with acute inflammation symptoms, neutropenia occurs, caused by the low neutrophil reserves in the body of cattle (ROLAND et al., 2014). This finding is in agreement with the findings of ORDEN et al. (2006). The other changes in the white blood cell parameters in the investigated cows are similar to those observed in rats in experimental studies (MALPUECH-BRUGÈRE et al., 2000; ORDEN et al., 2006).

The data obtained show that over the course of hypomagnesaemia in dairy cattle, haemolytic normocytic normochromic anaemia and eosinophilia occur. In each case when such changes are detected during routine haematological screening tests, the occurrence of $\mathrm{Mg}$ deficiency, especially in its chronic form, should be considered. Over the course of long-term treatment and supplementation with $\mathrm{Mg}$, haematological changes disappear, so for this reason, supplementation with an increased dose of $\mathrm{Mg}$ should be continued until all haematological parameters are stabilized.

\section{Conflicts of interest}

The authors declare that there are no conflicts of interest. 
B. Abramowicz et al.: The influence of magnesium deficiency on the haematological parameters of dairy cows.

\section{References}

BAIN, B. J. (2017): Howell-Jolly bodies in acute hemolytic anemia. Am. J. Hematol. 92, 473.

DOI: 10.1002/ajh.24624

BAUMGARTNER, W. (2005): Clinical Propaedeutic of Internal Diseases and Skin Diseases of Domestic Animals $6^{\text {th }}$ ed., Parey, Berlin, Germany, pp. 207-226 (in German).

CINAR, V., M. NIZAMLIOGLU, R. MOGULKOC, A. K. BALTACI (2007): Effects of magnesium supplementation on blood parameters of athletes at rest and after exercise. Biol. Trace Elem. Res. 115, 205-12.

DOI: $10.1007 / \mathrm{BF} 02685995$

COSENS, G., I. DIAMOND, L. L. THERIAULT, L. S. HURLEY (1977): Magnesium deficiency anemia in the rat fetus. Pediatr. Res. 11, 758-64.

ELIN, R. J., A. UTTER, H. K. TAN, L. CORASH (1980): Effect of magnesium deficiency on erythrocyte aging in rats. Am. J. Pathol. 100, 765-778.

GLOMBOWSKY, P., A. S. DA SILVA, N. M. SOLDÁ, G. M. GALli, A. H. BIAZUS, G. CAMPIGOTTO, N. B. BOTTARI, R. S. SOUSA, M. C. BRISOLA, L. M. STEFANI, M. D. BALDISSERA, M. L. R. LEAL, V. M. MORSCH, M. R. C. SCHETINGER, G. MACHADO (2018): Mineralization in newborn calves contributes to health, improve the antioxidant system and reduces bacterial infections. Microb. Pathog. 114, 344-349.

DOI: 10.1016/j.micpath.2017.12.012

GOFF, J. P. (2004): Macromineral disorders of the transition cow. Vet. Clin. North Am. Food Anim. Pract. 20, 471-494. DOI: 10.1016/j.cvfa.2004.06.003

GOFF, J. P. (2006): Macromineral physiology and application to the feeding of the dairy cow for prevention of milk fever and other periparturient mineral disorders. Anim. Feed Sci. Technol. 126, 237-257.

DOI: 10.1016/j.anifeedsci. 2005.08.005

GOFF, J. P. (2008): The monitoring, prevention, and treatment of milk fever and subclinical hypocalcemia in dairy cows. Vet. J. 176, 50-57.

DOI: $10.1016 / j . t v j 1.2007 .12 .020$

MALPUECH-BRUGÈRE, C., W. NOWACKI, M. DAVEAU, E. GUEUX, C. LINARD, E. ROCK, J. LEBRETON, A. MAZUR, Y. RAYSSIGUIER (2000): Inflammatory response following acute magnesium deficiency in the rat. Biochim. Biophys. Acta 1501, 91-98.

DOI: $10.1016 / \mathrm{s} 0925-4439(00) 00018-1$
MARTENS, H., M. SCHWEIGEL (2000): Pathophysiology of grass tetany and other hypomagnesemias. Implications for clinical management. Vet. Clin. North Food Anim. Pract. 16, 339-368.

ORDEN, Van R., D. L. EGGETT, K. B. FRANZ (2006): Influence of graded magnesium deficiencies on white blood cell counts and lymphocyte subpopulations in rats. Magnes. Res. 19, 93-101.

PIOMELLI, S., V. JANSEN, J. DANCIS (1973): The hemolytic anemia of magnesium deficiency in adult rats. Blood. 41, 451-459.

ROLAND, L., M. DRILLICH, M. IWERSEN (2014): Hematology as a diagnostic tool in bovine medicine. J. Vet. Diagn. Invest. 26, 592-598.

DOI: $10.1177 / 1040638714546490$

SCHONEWILLE, J. T., A. T. VAN'T KLOOSTER, H. WOUTERSE, A. C. BEYEN (1999): Effects of intrinsic potassium in artificially dried grass and supplemental potassium bicarbonate on apparent magnesium absorption in dry cows. J. Dairy Sci. 82, 1824-1830.

SHI, Z., X. HU, K. HE, B. YUAN, M. GARG (2008): Joint association of magnesium and iron intake with anemia among Chinese adults. Nutrition 24, 977-984.

DOI: 10.1016/j.nut.2008.05.002

SUTTLE, N. F. (2010): Mineral Nutrition of Livestock, $4^{\text {th }}$ ed., the British Library, London, UK pp. 92-121.

SWAMINATHAN, R. (2003): Magnesium metabolism and its disorders. Clin. Biochem. Rev. 24, 47-66.

YIN, Y., Q. LI, B. SUN, L. MA, J. MIAO, J. SUN, S. XI, Y. LI, X. WU, Y. ZHOU, Y. LIU (2015): Pilot study of the association of anemia with the levels of zinc, copper, iron, calcium, and magnesium of children aged 6 months to 3 years in Beijing, China. Biol. Trace Elem. Res. 168, 15-20. DOI: $10.1007 / \mathrm{s} 12011-015-0337-0$

ZHAN, Y., R. CHEN, W. ZHENG, C. GUO, L. LU, X. JI, Z. CHI, J. YU (2014): Association between serum magnesium and anemia: china health and nutrition survey. Biol. Trace Elem. Res. 159, 39-45.

DOI: $10.1007 / \mathrm{s} 12011-014-9967-\mathrm{x}$
Received: 28 March 2020

Accepted: 11 May 2020 


\section{ABRAMOWICZ, B., K. LUTNICKI, Ł. KUREK: Utjecaj kliničkih i kroničnih oblika nedostatka magnezija na hematološke parametre mliječnih krava. Vet. arhiv 91, 117-124, 2021. \\ SAŽETAK}

Cilj rada bio je utvrditi utjecaj hipomagnezijemije na hematološki status i prediktivne vrijednosti hematoloških testova za dijagnozu nedostatka magnezija $(\mathrm{Mg})$ u stadima mliječnih krava. Istraživanje je provedeno na 100 mliječnih krava holštajn-frizijske pasmine, koje su podijeljene u tri skupine: dvije pokusne i jednu kontrolnu. Dvije pokusne skupine (I - klinički oblik hipomagnezijemije, II - kronični oblik hipomagnezijemije) sastojale su se od po 40 krava, a kontrolna skupina sastojala se od 20 zdravih krava. Uzorci krvi prikupljeni su dva puta: prije početka terapije i poslije tri mjeseca. U obje hipomagnezijemijske skupine primijećene su niske vrijednosti broja eritrocita, koncentracije hemoglobina i indeksa hematokrita. Neizravni parametri eritrocitnog sustava bili su unutar standardnog referentnog raspona, s izuzetkom indeksa prosječnog hemoglobin u eritrocitu, koji je u oko 42 \% životinja bio ispod donje granice referentnog raspona. Hipomagnezijemiju krava pratila je normocitna, normokromna anemija. U prvoj i drugoj skupini pri prvom je uzorkovanju krvi uočeno povećanje broja eozinofila, što je bilo statistički znakovito u odnosu na drugo uzorkovanje. Provođenjem pretrage krvnog razmaza u krava za hipomagnezijemijom otkriveni su različite veličine eritrocita (anisocitoza), polikromazija i Howell-Jollyjeva tjelešaca. Nakon dodatka magnezija, njegova se koncentracija u serumu liječenih životinja vratila u normalu brže od hematoloških parametara. Autori pretpostavljaju da spomenute promjene hematoloških vrijednosti mogu pomoći u otkrivanju potrebe za dodavanje magnezija u hranidbi mliječnih krava.

Ključne riječi: hematologija; hipomagnezijemija; goveda; hemolitička anemija 